SAlton, M. R. J. (1958). J. gen. Microbiol. 18, 481-490

\title{
The Lysis of Micro-organisms by Lysozyme and Related Enzymes
}

\author{
By M. R. J. SALTON \\ Department of Bacteriology, University of Manchester
}

'Lysozyme' was the name given by Fleming (1922) to an enzyme, present in various tissues and secretions, which possessed the ability to lyse the cells of many microbial species. Of all the sources tested for 'lysozyme' activity, Fleming (1922) found that egg white contained the highest amounts. Because of the abundance of egg white as a source of enzyme, the action of egg-white lysozyme on micro-organisms has been investigated more fully than "lysozymes' from other tissues. Alderton, Ward \& Fevold (1945) succeeded in isolating lysozyme from egg white in the form of a crystalline protein, and in sufficient yield to determine its homogeneity and physico-chemical properties. Enzymes possessing lytic activities in common with egg-white lysozyme have been isolated as crystalline proteins or protein derivatives from rabbit spleen (Jollès \& Fromageot, 1954) and from papaya latex (Smith, Kimmel, Brown \& Thompson, 1955). The lysozymes thus obtained from egg white, rabbit spleen and papaya latex, have several features in common. They are basic proteins of comparatively low molecular weights (c. 14,000 for eggwhite and rabbit-spleen enzymes and $c .24,000$ for papaya-latex enzyme, Fevold, 1951; Jollès \& Fromageot, 1954; Smith et al. 1955) are devoid of sulphydryl groups and have rather similar numbers of residues of certain amino acids. Egg-white lysozyme and the rabbit-spleen enzyme have lysine as the $N$-terminal amino acid and leucine as the $C$-terminal amino acid (data recently summarized by Salton, $1957 a$ ).

Apart from the similarities in the range of micro-organisms lysed, there is no detailed information about the nature of the bonds broken by the enzymes from rabbit spleen and papaya latex. The lytic properties of purified enzymes related to egg-white lysozyme have been reported by a number of investigators, e.g. the enzyme from polymorphonuclear leucocytes (Epstein \& Chain, 1940); plakin (Amano, Kato \& Shimizu, 1952); bacterial lysozyme from Bacillus subtilis (Richmond, 1957). The bacterial enzyme described by Richmond (1957) appears to be very similar to egg-white lysozyme, especially in respect of the nature of the non-dialysable products obtained by its action on cell-wall substrates. Although many of the above-mentioned enzymes are closely related to egg-white lysozyme and may eventually be shown to act on similar substrate groups, the subsequent use of the term 'lysozyme' in this paper, will apply only to egg-white lysozyme, for it has been this enzyme that has been used in determining the manner in which lysozyme acts upon microorganisms. 


\section{The action of lysozyme on Gram-positive bacteria}

The lytic action of lysozyme on bacteria can be ascribed simply to the dissolution of the rigid cell-wall structures. When the degradation of the wall occurs in dilute media, the underlying structures of a lysozyme-sensitive bacterial cell will collapse and the liberation of the cytoplasmic components into the medium will result in the lysis of the bacterial suspension. However, Weibull (1953) showed that dissolution of the wall of Bacillus megaterium in the presence of osmotically protective quantities of sucrose was accompanied by liberation of bacterial protoplasts and only partial optical clearing of the cell suspension. Although protoplast formation may account for incomplete lysis of bacterial suspensions when treated with lysozyme under appropriate conditions, it is evident that the walls of bacteria differ quantitatively in the 'amount' of lysozyme substrate present and such a factor as this may contribute to the partial optical clearing in dilute media.

For a detailed investigation of the mechanism of lysozyme action, three Gram-positive bacteria whose isolated walls were completely digested by lysozyme were selected (Salton, 1956a). On incubation with crystalline eggwhite lysozyme, the walls of Micrococcus lysodeikticus, Sarcina lutea and Bacillus megaterium are digested with a liberation of reducing and acetyl amino sugar groups. Lysozyme activity may be followed by measuring the decrease in the turbidity of the cell-wall suspensions and by estimating the amounts of liberated reducing substances. With cell walls of the abovementioned organisms, the optimum $\mathrm{pH}$ value for lysozyme activity as determined by the decrease in turbidity or liberation of reducing substances, is between $\mathrm{pH} 6.5$ and $7 \cdot 0$. The optimum $\mathrm{pH}$ value for the liberation of reducing groups is sensitive to variations in the ionic strengths of the buffer systems, discontinuities appearing in the $\mathrm{pH}$ curves when the ionic strengths are not controlled at constant values. The dissolution of the walls of $\boldsymbol{M}$. lysodeikticus by lysozyme shows a broad optimum ionic strength requirement of $\mu=0 \cdot 1$ (Salton \& Ghuysen, 1957). This is in marked contrast to the very narrow ionic strength optima observed by Ghuysen (1957) for the action of his purified enzymes from Streptomyces albus on certain intact bacteria and cell-wall substrates.

The products resulting from the digestion of the walls of Micrococcus lysodeikticus, Sarcina lutea and Bacillus megaterium are complex mixtures of fragments of differing molecular sizes (the largest fragments have molecular weights of the order of 10,000-20,000) and electrophoretic properties (Salton, $1956 a$ ). The larger non-dialysable fragments and the dialysable fractions give acetyl amino sugar reactions. The main dialysable substance liberated by lysozyme appears to be a disaccharide of acetylglucosamine and acetyl 'muramic acid' ('muramic acid' is the name Strange has suggested for an acidic amino sugar isolated from bacterial cell walls and spore peptides by Strange \& Dark, 1956; Strange (1956) has provisionally proposed the structure of 'muramic acid' as 3-O- $\alpha$-carboxyethyl hexosamine). The cell-wall amino acids and sugars are not detectable as the free substances in the dialysable 
fractions of the digests. The available evidence thus suggests that lysozyme is splitting the glycosidic bonds of the cell-wall amino sugars, liberating the disaccharide of acetylglucosamine and acetyl 'muramic acid' as the simplest product, together with more complex fragments which differ quantitatively rather than qualitatively in their chemical composition. It is not known at present, whether the cell-wall amino sugars are linked by $\alpha$-or $\beta$-glycosidic bonds. That the main action of lysozyme is one involving amino sugar bonds is further strengthened by the observation that it also attacks cell walls with their free amino groups blocked by reaction with 1-fluoro-2:4-dinitrobenzene (FDNB) at about the same rate as the untreated walls (Ingram \& Salton, 1957). There is, however, an increase in the number of $N$-terminal alanine molecules after the walls have been digested with lysozyme. If this is not due merely to the more complete reaction of the soluble digested walls with FDNB, as compared with insoluble walls, then it must be assumed that there is a subsidiary action of lysozyme on other parts of the cell-wall structure. However, the increase in terminal alanine groups after digestion is small in comparison with the liberation of reducing groups (Ingram \& Salton, 1957).

In more recent investigations I have been endeavouring to find out whether lysozyme sensitivity is correlated with any special features of the composition of the cell walls-in effect to see whether one could 'diagnose' the lysozyme substrate from the quality and/or quantity of cell-wall constituents. From the many lytic tests reported for the sensitivity of intact cells of a large number of micro-organisms, it seemed likely that a whole 'spectrum of sensitivities' to lysozyme might be expected when tests were performed on isolated cell walls. This has indeed proved to be so and the results of the dissolution of the walls of various staphylococci and micrococci by lysozyme, presented in Fig. 1. illustrate such a range of susceptibilities to digestion. The final degrees of decrease in turbidity after $24 \mathrm{hr}$.-incubation with lysozyme, varied from $\mathbf{3 2} \%$ for Staphylococcus citreus to $80 \%$ for Micrococcus roseus and $98 \%$ for Sporosarcina ureae. It seems probable that a similar 'spectrum of sensitivities' exists for members of the genus Bacillus; B. megaterium cell walls are completely digested by lysozyme, whereas walls of $\boldsymbol{B}$. subtilis and $\boldsymbol{B}$. cereus are only partially dissolved (c. $50 \%$ turbidity decrease in both instances) and the rate of dissolution of the walls of the latter organism is much lower than that observed for the other species (Salton, 1956b).

The principal amino acid, amino sugar and sugar constituents of the various cell walls showing different sensitivities to lysozyme, have been determined by paper chromatographic examinations of hydrolysed walls $(6 \mathrm{~N}-\mathrm{HCl}$ for amino acids; $2 \mathrm{~N}-\mathrm{H}_{2} \mathrm{SO}_{4}$ for sugars; amino sugars detectable under both conditions of acid hydrolysis). The major amino acid, amino sugar and sugar constituents found in the walls are summarized in Table 1 and data on the lysozyme sensitivity and contents of amino sugar are presented in Table 2 . These results, in common with the more extensive surveys reported by Cummins \& Harris $(1956 a, b)$, have shown that alanine, glutamic acid, glucosamine and 'muramic acid' are present in the cell walls of all of the Gram-positive bacteria so far investigated. Inspection of the results given in Tables 1 and 2 shows that 
there is no qualitative or quantitative correlation between cell-wall constituents and sensitivity to lysozyme. Thus both 'lysozyme-sensitive' and 'lysozyme-resistant' bacterial cell walls contain alanine, glutamic acid and the two amino sugars. A comparison of the amino sugar contents of the resistant walls of Streptococcus faecalis $(22 \%)$ and the partially-sensitive walls of

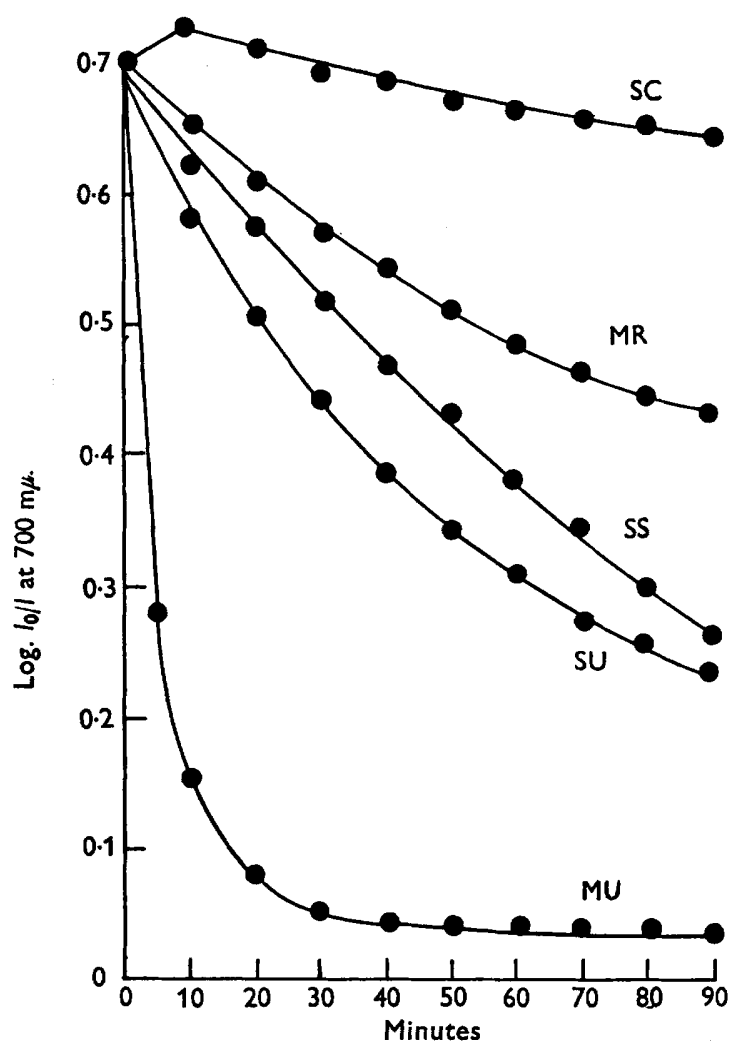

Fig. 1. The action of lysozyme on the cell walls of SC (Staphylococcus citreus), MR (Micrococcus roseus), SS (Staphylococcus saprophyticus), SU (Sporosarcina ureae), MU (Micrococcus urea). Cell walls treated with lysozyme $(50 \mu \mathrm{g} . / \mathrm{ml}$. final concentration; pH 7; $37^{\circ}$ ), and turbidity decrease followed by measurement in the Unicam spectrophotometer, model SP 600 .

Bacillus cereus (31 \% amino sugars), with those of the susceptible Micrococcus lysodeikticus (16-18\%) and B. megaterium (18\%), shows no relationship between this factor and lysozyme susceptibility. It is therefore clear that at the present moment we cannot predict the lysozyme sensitivity of the wall of a particular bacterial species by simple chromatographic identification of its constituents or by estimation of the amino sugar contents. Such a situation is perhaps not surprising since mere identification and even estimation of cellwall constituents tells us nothing of the arrangement of the amino acid, amino sugar or sugar molecules in the polymerized cell-wall structure. The presence 
of galactosamine in the walls of $S$. faecalis and those of Clostridium welchii may be correlated with their resistance, but until more species containing all three amino sugars in their walls have been examined for lysozyme sensitivity, such a correlation must remain a superficial one. Thus it seems improbable that we

Table 1. Amino acid, amino sugar and sugar constituents of cell walls

Cell walls

(arranged in order of decreasing sensitivity to lysozyme) of Gram-negative bacteria

Micrococcus lysodeikticus

Sarcina lutea

Sporosarcina ureae

Staphylococcus saprophyticus

Micrococcus varians

Bacillus megaterium

Micrococcus tetragenus

$M$. roseus

Bacillus subtilis

B. cereus

Staphylococcus citreus

Streptococcus faecalis

Clostridium welchii

\begin{tabular}{ccccccccccc}
\multicolumn{4}{c}{ Amino acids } & \multicolumn{3}{c}{ Amino sugars } & \multicolumn{3}{c}{ Sugars } \\
$\overbrace{\text { Al }}^{\text {Glu }}$ & Ly & Gly & DAP & $\overbrace{\text { Gluca }}^{\text {Gala }}$ & Mur & Gluc & Gal & Rham \\
+ & + & + & + & - & + & - & + & + & - & - \\
+ & + & + & + & - & + & - & + & + & - & - \\
+ & + & + & + & - & + & - & + & - & - & - \\
+ & + & + & + & - & + & - & + & + & tr & - \\
+ & + & - & + & + & + & - & + & + & - & - \\
+ & + & - & - & + & + & - & + & - & + & - \\
+ & + & + & + & - & + & - & + & + & tr & - \\
+ & + & + & - & - & + & - & + & - & + & - \\
+ & + & - & - & + & + & - & + & + & - & - \\
+ & + & - & - & + & + & - & + & + & - & - \\
+ & + & + & + & - & + & - & + & + & - & - \\
+ & + & + & + & - & + & + & + & + & + & + \\
+ & + & - & + & + & + & + & + & + & - & +
\end{tabular}

Abbreviations: Amino acids: Al, alanine; Glu, glutamic acid; Ly, lysine; Gly, glycine; DAP, diaminopimelic acid. Amino sugars: Gluca, glucosamine; Gala, galactosamine; Mur, 'muramic acid'. Sugars: Gluc, glucose; Gal, galactose; Rham, rhamnose.

N.B. No attempt has been made to indicate the relative proportions of cell-wall constituents.

Table 2. Lysozyme sensitivity and amino sugar contents of cell roalls of Gram-negative bacteria

\begin{tabular}{|c|c|c|}
\hline Cell walls from & $\begin{array}{l}\text { Order of decreasing } \\
\text { sensitivity to } \\
\text { lysozyme } \\
\text { (\% turbidity decrease) }\end{array}$ & $\begin{array}{c}\% \text { amino sugar } \\
(2 \mathrm{~N}-\mathrm{HCl} \\
\text { hydrolysates })\end{array}$ \\
\hline Micrococcus lysodeikticus & $>90$ & $16-18$ \\
\hline Sarcina lutea & $>90$ & 14-16 \\
\hline Sporosarcina ureae & $>90$ & 14 \\
\hline Staphylococcus saprophyticus & $>90$ & 14 \\
\hline Micrococcus varians & $>90$ & 10 \\
\hline Bacillus megaterium & $>90$ & 18 \\
\hline Micrococcus tetragenus & $50-90$ & 13 \\
\hline M. roseus & $50-90$ & 15 \\
\hline Bacillus subtilis & 50 & $8 \cdot 5$ \\
\hline B. cereus & 50 & 31 \\
\hline Staphylococcus citreus & $<50$ & 10 \\
\hline Streptococcus faecalis & $<10$ & 22 \\
\hline Clostridium welchii & $<10$ & - \\
\hline
\end{tabular}

shall be able to explain the factors responsible for the susceptibility of some bacterial walls to lysozyme until we know more about the frequency with which the disaccharide occurs in the wall and the way in which the amino sugars are linked to one another and to other cell-wall constituents. 


\section{The action of lysozyme on Gram-negative bacteria}

As a group the Gram-negative bacteria have fewer members as sensitive to lysozyme as some of the Gram-positive species from the genus Micrococcus or from the genus Bacillus. However, it is evident that some Gram-negative bacteria are at least as susceptible to lysis by lysozyme as the more resistant species of Gram-positive bacteria. Thus Brucella abortus is lysed by lysozyme and appreciable quantities of the substrate can be extracted from the cells (Epstein \& Chain, 1940). Unlike the Gram-positive bacteria, the lysozyme sensitivity of intact cells of many Gram-negative organisms can often be established only after the application of special techniques such as the following: (1) the addition of sodium hydroxide solutions after exposure to lysozyme under the conditions described by Nakamura (1923); (2) incubation with lysozyme at low $\mathrm{pH}$ values $($ c. 3.5$)$ at $45^{\circ}$ followed by the addition of alkali c. pH 10 (Peterson \& Hartsell, 1955; Grula \& Hartsell, 1957 a, b); (3) prior treatment of bacteria with acetone or heat (Warren, Gray \& Bartell, 1955); (4) treatment with lysozyme in the presence of 'Versene' (ethylenediamine tetra-acetic acid-EDTA) as reported by Repaske (1956). Thus with many Gram-negative bacteria, the lysis due to lysozyme is often negligible, but the contribution due to lysozyme when the treatment is combined with any of the above procedures, is frequently quite large. Grula \& Hartsell $(1957 a, b)$ determined the $\%$ changes in optical densities of bacterial suspensions due to the addition of alkali and due to the combined action of lysozyme and subsequent treatment with alkali. The results showed that lysozyme contributed to a greater or lesser degree to the optical clearing of suspensions of all organisms except Brucella suis. This work again indicates that the differences in susceptibility to the lytic action of lysozyme are quantitative rather than qualitative.

Because the chemical constitution of the cell walls of Gram-negative bacteria differ in a number of respects from those of Gram-positive organisms (Salton, 1953; 1957b), the question of their sensitivity to lysozyme has become an intriguing problem. The major components of the walls of many Gram-negative bacteria are proteins, lipids and polysaccharides. In contrast to this, the walls of Gram-positive bacteria are of muco-complex nature, containing peptides and amino sugar and sugar constituents with little or no lipid (Salton, 1953). The walls of all of the Gram-negative bacteria so far examined, contain glucosamine, 'muramic acid' and diaminopimelic acid (DAP) (Salton, 1957 $b$ ). Thus the two amino sugars are common to cell walls from organisms of both Gram-positive and Gram-negative groups. As shown in Table 3, the amino sugar contents of the cell walls of Gram-negative bacteria are generally lower than those of walls from Gram-positive organisms.

When the isolated cell walls of certain Gram-negative bacteria are incubated with lysozyme under conditions giving complete digestion of the walls of a sensitive organism such as Micrococcus lysodeikticus, only a small turbidity decrease can be detected. For example, the walls of a strain of Escherichia coli showed a maximum turbidity decrease of $4 \%$ on incubation with lysozyme 
(100 $\mu$ g. crystalline egg-white lysozyme/ml.; pH 7; ionic strength $\mu=0 \cdot 1$; $\mathbf{3 7} 7^{\circ} \mathbf{2 4} \mathrm{hr}$.) and the corresponding value for walls of Salmonella gallinarum was $19 \%$. However, despite the small changes in turbidity, an examination of the insoluble and soluble fractions of walls from $E$. coli, S. gallinarum, a psychrophilic strain of Pseudomonas sp. and Chlorobium thiosulphatophilum after incubation with lysozyme, has given some indication of the nature of lysozyme action on these structures.

Table 3. Amino sugar content of the cell ralls of Gram-negative bacteria

$\begin{array}{lc}\text { Cell walls from } & \begin{array}{c}\text { \% amino sugar } \\ \text { Escherichia coli }\end{array} \\ \text { Spirillum serpens } & 2 \cdot 2-4 \cdot 0 \\ \text { Chlorobium thiosulphatophilum } & 6 \cdot 8 \\ \text { Rhodospirillum rubrum } & 4 \cdot 2 \\ \text { Vibrio metchnikovi } & 2 \\ \text { Salmonella pullorum } & 1 \cdot 9 \\ \text { S. gallinarum } & 4 \cdot 8 \\ \text { Organism LC 1* } & 3 \cdot 9\end{array}$

* A Gram-negative coccus described by Elsden, Volcani, Gilchrist \& Lewis (1956).

Table 4. Amino sugar contents of cell walls and lysozyme-insoluble wall fractions of two Gram-negative bacteria

\begin{tabular}{|c|c|c|}
\hline & $\begin{array}{l}\text { Original } \\
\text { cell wall }\end{array}$ & $\begin{array}{c}\text { Lysozyme- } \\
\text { insoluble } \\
\text { residues }\end{array}$ \\
\hline & \multicolumn{2}{|c|}{$\begin{array}{c}\% \text { amino sugars } \\
\text { (2N-HCl hydrolysates) }\end{array}$} \\
\hline Chlorobium thiosulphatophilum & $4 \cdot 2$ & $0 \cdot 7$ \\
\hline Salmonella gallinarum & $\mathbf{3 \cdot 9}$ & $1 \cdot 8$ \\
\hline
\end{tabular}

The soluble, non-dialysable components released by lysozyme from the walls of the above Gram-negative bacteria, contained alanine, glutamic acid, DAP and glucosamine as the predominant substances, with smaller amounts of 'muramic acid' and a number of other amino acids. The most conspicuous features of the paper chromatograms of the hydrolysed, lysozyme-insoluble residues, were the presence of all of the original cell-wall amino acids, with the exception of DAP which was detectable only in trace amounts, the presence of glucosamine, and only faint traces of 'muramic acid'. A comparison of paper chromatograms from the hydrolysed insoluble residues with those from the hydrolysed soluble, non-dialysable fractions, also showed that all but a trace of the cell-wall tyrosine was located in the lysozyme-insoluble wall fraction. The changes in amino sugar components indicated by paper chromatography have been confirmed for several preparations by determining the amino sugar contents of the original preparations and the insoluble residues after lysozyme action. These data are given in Table 4. 
Thus lysozyme action on the cell walls of the Gram-negative bacteria, used in this investigation, deprives the residual cell-wall structures of most of their DAP and 'muramic acid', and releases a soluble component in which alanine, glutamic acid and DAP are the principal amino acid constituents. Such a product composed of glucosamine, 'muramic acid' and a limited range of amino acids is obviously related to the class of substances forming the entire framework of the cell walls of many Gram-positive bacteria. These results, considered in the light of the effects of the Nakamura technique (Grula \& Hartsell, 1957 $a, b$ ), EDTA (Repaske, 1956) and disaggregating agents such as sodium dodecyl sulphate (Salton, $1957 c$ ), give us a clearer picture of the architecture of the walls of some Gram-negative bacteria. The evidence so far available suggests that the walls of Gram-negative bacteria are composed of two main structural entities: (1) a rigid muco-complex component of the type forming the entire wall of many Gram-positive bacteria; this component may form the rigid 'backbone' of the cell wall and be responsible for the characteristic shape of a particular Gram-negative species; (2) a structurally less rigid lipoprotein component, held together by weaker bonds that would be susceptible to reagents (e.g. EDTA, sodium dodecyl sulphate) capable of disaggregating lipoprotein complexes. The relative proportions of the two components in the walls probably vary from one species to another.

The dual features of the cell-wall structure of Gram-negative bacteria suggested above is compatible with observations of the loss of cell-wall rigidity and of 'protoplast' formation by lysozyme treatment of Escherichia coli at high $\mathrm{pH}$ values (Zinder \& Arndt, 1956) or with 'Versene' (Mahler \& Fraser, 1956) and the production of 'protoplasts' of Escherichia coli on media containing penicillin (Lederberg, 1956). Recent experiments performed by Dr F. Shafa and myself have indicated that both lysozyme action and penicillin action probably involve the same type of structure in the cell walls of certain Gram-negative bacteria. The two organisms Vibrio metchnikovi and Salmonella gallinarum are readily transformed to spherical forms (so-called 'protoplasts') on media containing penicillin, and this transformation is accompanied by a loss of cell-wall amino sugar and DAP. Although the cell walls of these organisms are not destroyed during this spherical transformation (or 'protoplast' formation) on penicillin agar media, it is evident that the synthesis of the components essential for the rigidity of the cell-wall structure blocked by penicillin and the pre-existing muco-complex components of the wall are probably then 'diluted out'. Thus any treatment of Gram-negative micro-organisms effecting a loss of cell-wall muco-complex, either by direct enzymic degradation as with lysozyme, or by blocked synthesis as with penicillin, will result in a more plastic cell-wall structure of the lipoprotein type.

I wish to thank Mr G. Pavlik for valuable technical assistance, Dr J. L. Peel and Dr J. Gibson for a generous gift of the organisms LC1 and Chlorobium thiosulphatophilum, and Mr A. D. Brown for the cell-wall preparation of the Pseudomonas sp. 


\section{REFERENCES}

Alderton, G., Ward, W. H. \& Frvold, H. L. (1945). Isolation of lysozyme from egg white. J. biol. Chem. 157, 43.

Amano, T., Kato, K. \& Shimizu, R. (1952). Studies on the role of plakin. Med. J. Osaka Univ. 3, 293.

Cummins, C. S. \& HARRIS, H. $(1956 a)$. The chemical composition of the cell walls in some Gram-positive bacteria and its possible value as a taxonomic character. J. gen. Microbiol. 14, 583.

Cummins, C. S. \& Harris, H. $(1956 b)$. The relationships between certain members of the Stapylococcus and Micrococeus group as shown by their cell wall composition. Int. Bull. bact. Nomen. Taxon. 6, 111.

Elsden, S. R., Volcani, B. E., Gilchist, F. M. C. \& Lewis, D. (1956). Properties of a fatty acid forming organism isolated from the rumen of sheep. J. Bact. 72, 681.

Epstein, L. A. \& Chain, E. (1940). Some observations on the preparation and properties of the substrate of lysozyme. Brit. J. exp. Path. 21, 339.

Fevold, H. L. (1951). Egg proteins. Advanc. Protein Chem. 6, 187.

Fleming, A. (1922). On a remarkable bacteriolytic element found in tissues and secretions. Proc. Roy. Soc. B, 93, 306.

Ghuysen, J. M. (1957). Activités bactériolytiques de l'actinomycetine de Streptomyces albus. Arch. int. Physiol. 65, 174.

Grula, E. A. \& Hartsell, S. E. (1957 a). Lysozyme in the bacteriolysis of Gramnegative bacteria. I. Morphological changes during use of Nakamura's technique. Canad. J. Microbiol. 3, 13.

Grula, E. A. \& Hartsell, S. E. (1957 b). Lysozyme in the bacteriolysis of Gramnegative bacteria. II. Factors influencing clearing during the Nakamura treatment. Canad. J. Microbiol. 3, 23.

INGRAM, V. M. \& SAlton, M. R. J. (1957). The action of fluorodinitrobenzene on bacterial cell walls. Biochim. biophys. Acta, $24,9$.

Jollès, G. \& Fromageot, C. (1954). La protéine lysant II de la rate du lapin. Biochim. biophys. Acta, 14, 219.

Lederberg, J. (1956). Bacterial protoplasts induced by penicillin. Proc. nat. Acad. Sci., Wash. 42, 574.

Mahler, H. R. \& Fraser, D. (1956). Reproduction of bacteriophage T3 in protoplasts of Escherichia coli, strain B. Biochim. biophys. Acta, 22, 197.

Nakamura, O. (1923). Über Lysozymwirkungen. Z. ImmunForsch. 38, 425.

Peterson, R. G. \& Hartsell, S. E. (1955). The lysozyme spectrum of the Gramnegative bacteria. J. infect. dis. 96, 75.

REPASKe, R. (1956). Lysis of Gram-negative bacteria by lysozyme. Biochim. biophys. Acta, 22, 189.

Richmond, M. (1957). Bacterial lysozyme. J. gen. Microbiol. 16, iv.

SALton, M. R. J. (1953). The composition of the cell walls of some Gram-positive and Gram-negative bacteria. Biochim. biophys. Acta, 10, 512.

Salton, M. R. J. $(1956 a)$. The action of lysozyme on cell walls of some lysozyme sensitive bacteria. Biochim. biophys. Acta, 22, 495.

Salton, M. R. J. (1956b). Cellular Structure and Enzymic Bacteriolysis, pp. 404. Proc. 3rd int. Congr. Biochem. (Brussels). New York: Academic Press.

SALton, M. R. J. (1957 a). The properties of lysozyme and its action on microorganisms Bact. Rev. 21, 82.

Salton, M. R. J. $(\mathbf{1 9 5 7} b)$. Cell-wall amino-acids and amino-sugars. Nature, Lond. $180,338$.

Salton, M. R. J. $(1957 c)$. The action of lytic agents on the surface structures of the bacterial cell. 2nd International Conference on Surface Activity (London). Preprints p. FI. 274. London: Butterworths. 
Salton, M. R. J. \& Ghuysen, J. M. (1957). Action de l'actinomycetine sur les parois cellulaires bactériennes. Biochim. biophys. Acta, 24, 160.

Smith, E. L., Kimmel, J. R., Brown, D. M. \& Thompson, E. O. P. (1955). Isolation and properties of crystalline mercury derivative of a lysozyme from papaya latex. J. biol. Chem. 215, 67.

Strange, R. E. (1956). The structure of an amino sugar present in certain spores and bacterial cell walls. Biochem. J. 64, 23 P.

Strange, R. E. \& Dark, F. A. (1956). An unidentified amino sugar present in cell walls and spores of various bacteria. Nature, Lond. 177, 186.

Warren, G. H., Gray, J. \& Bartell, P. (1955). The lysis of Pseudomonas aeruginosa by lysozyme. J. Bact. 70, 614 .

Weibuld, C. (1953). The isolation of protoplasts from Bacillus megaterium by controlled treatment with lysozyme. J. Bact. 66, 688.

Zinder, N. D. \& ARndt, W. F. (1956). Production of protoplasts of Escherichia coli by lysozyme treatment. Proc. nat. Acad. Sci., Wash. 42, 586. 